\title{
A health survey of selected stocks of commercially exploited Norwegian bivalve molluscs
}

\author{
Stein H. Mortensen \\ Institute of Marine Research, Department of Aquaculture, PO Box 1870, N-5024 Bergen-Nordnes, Norway
}

\begin{abstract}
This paper describes the first systematic health survey of commercially exploited bivalve molluscs in Norway. The main aim of the work was to screen selected stocks of the native flat oyster Ostrea edulis and the introduced Manila clam Ruditapes philippinarum for the presence of pathogenic agents. Samples were also collected from the indigenous clam Ruditapes decussatus and the scallop Pecten maximus, as well as from the introduced Pacific oyster Crassostrea gigas. The indigenous and cultured blue mussel Mytilus edulis and the Iceland scallop Chlamys islandica were not included. No abnormal mortalities were registered, nor were any serious pathogenic agents detected. Some tissue anomalies and some commensals or parasites were reported. These included thigmotrich ciliates on gills and in digestive diverticula, and intracytoplasmic Rickettsiales-like inclusions in epithelia of digestive gland diverticula of oysters, and a cyclopoid Modiolicola like copepod on scallop gills. Polymorphic, presumably inorganic, granulations were observed in connective tissues of oysters. Mature gonads were observed in the Manila clams. Based on the results, some advice on monitoring and management of the stocks is offered.
\end{abstract}

\section{INTRODUCTION}

The farming of the native European flat oyster Ostrea edulis (Linnaeus, 1750) has a long tradition in Norway (Helland-Hansen 1908, Gaarder \& Bjerkan 1934), although the cultivation of any bivalve mollusc species in Norway has always remained a minor industry. In recent years a few companies have aimed at commercial production of both indigenous species $\mid O$. edulis, the venerid clam Ruditapes decussatus (Linnaeus, 1758) and scallops Pecten maximus (Linnaeus 1758)] and introduced species [the Pacific oyster Crassostrea qigas (Thunberg, 1793), and the Manila clam Ruditapes philippinarum (Adams \& Reeve, 1850)]. The Pacific oysters were introduced for the first time to Norway from Northern Ireland in 1979, and broodstock Manila clams from Scottish farms in 1987.

As no severe mortalities have been recorded in Norwegian stocks, these mollusc species have been considered free from diseases. However, no systematic histological investigations had been performed. When the zoosanitary control systems within the European
Community were standardized (Anonymous 1991), satisfactory monitoring of Norwegian stocks of commercially exploited bivalve molluscs was considered an important need.

Both broodstock and spat oysters and clams have been moved between different areas (Fig. 1A) without any previous examination, and oyster spat have been distributed to several grow-out sites along the Norwegian western coast. Thus, at present, the southern and western coast of Norway has to be considered as one zoosanitary zone. One of the main production units is located in Espevik at Tysnes outside Bergen (Fig. 1B, C). This unit combines production in a closed lagoon or 'poll' (this term is defined in e.g. Matthews \& Heimdal 1980) with hatchery and nurseries. At Espevik European flat oysters, Pacific oysters, indigenous and Manila clams are all stocked within the facilities, and this was therefore chosen as the main sampling site. Occasionally oysters were also received from Vågstranda and from Rognvoll in Trøndelag. Scallops were collected in the area around the island of Sotra, west of Bergen. 
A

B
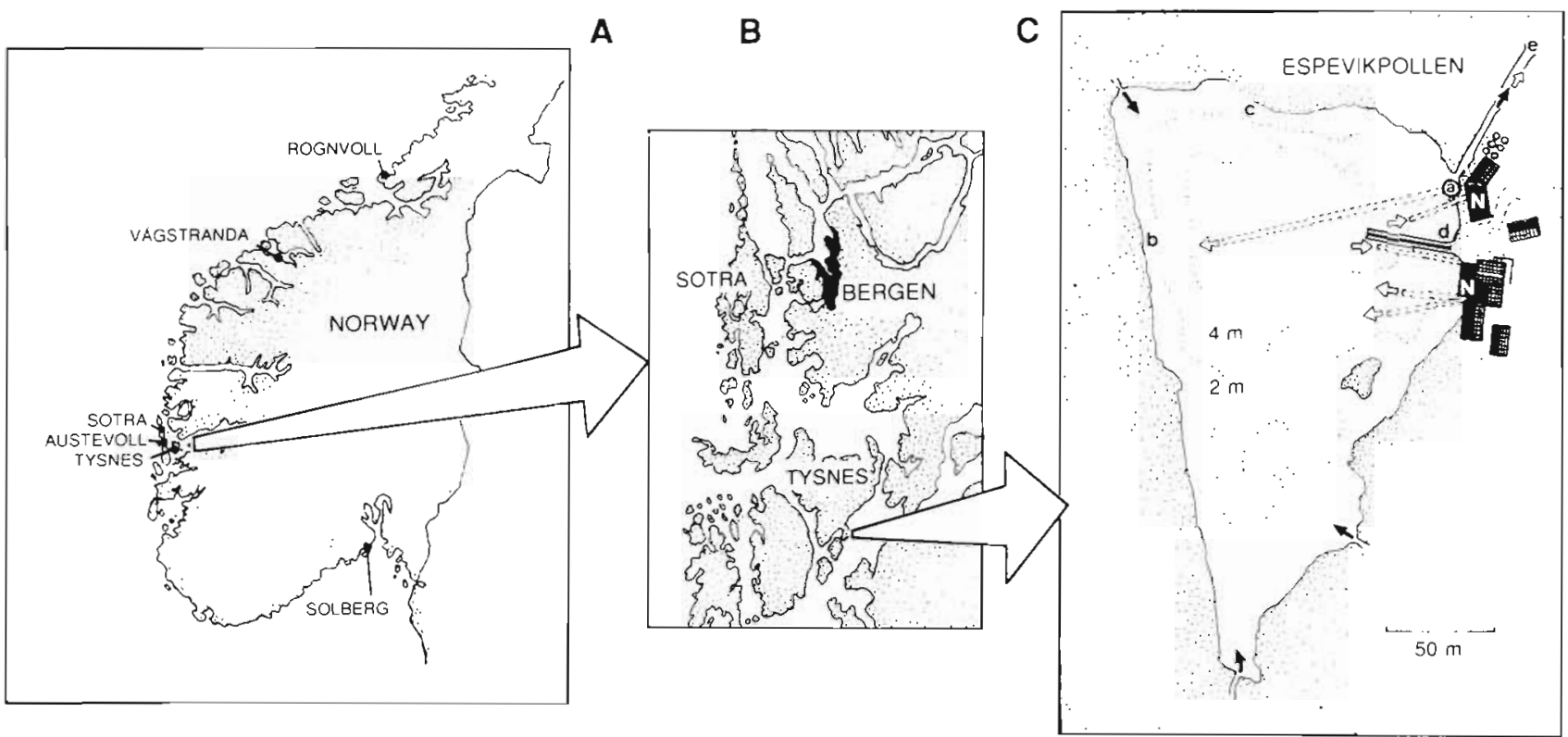

Fig. 1. (A) Southern part of Norway and some areas among which oysters have been moved. (B) Detail from (A). (C) Oyster poll and production facilities at Espevik, Tysnes. Nurseries are marked ' $N$ ', black arrows show natural inlets of freshwater and effluent (e). White arrows show directions of actively pumped water. 'a' is mixing tank for fertilizer; ' $a$ ' to 'e' are sampling points in the poll

As filter feeders, bivalve molluscs will always be inhabited by commensals, mutualists and opportunists. Thus the aim of the present examinations was not to describe the total microfauna in the bivalves, but primarily to look for known pathogenic microorganisms, as listed by the Office International des Epizooties (De Kinkelin et al. 1990), and other potentially diseasecausing agents.

Bivalve molluscs are considered as vectors of various pathogenic agents, probably also including fish pathogenic viruses (Hill 1982, Mortensen et al. 1992). Potential dispersal of such viruses with movements of live bivalve molluscs would be unacceptable from a fish health management point of view. As Infectious Pancreatic Necrosis Virus (IPNV) has been isolated from both scallops Pecten maximus (Mortensen et al. 1990) and mussels Mytilus edulis (author's unpubl. data) in Norway, a virological assay was performed for each species at each sampling

\section{MATERIAL AND METHODS}

Sampling and observations on site. At Espevik, bivalves were sampled at or in the vicinity of the hatchery, or in the effluent (water which had passed through the facilities) (Fig. 1C).

Sampling of flat oysters and Manila clams has been performed at Espevik each spring and autumn since autumn 1989. For all 5 species examined, the time, sampling sites and number of specimens are listed in Table 1. For fish, a sample size of 150 corresponds to the number of individuals required to detect latent carriers at a minimum of $2 \%$ prevalence on a $95 \%$ confidence level. This sample size was chosen for 2 samplings of flat oysters and 1 sampling of Manila clams. In addition to those listed in Table 1, 20 to 40 extra specimens were opened at each sampling, for observation of gross morphology.

The poll (Fig, 1C) was inspected by diving in August 1989, August 1990 and March 1992.

Gross morphology. Shells and soft parts of all specimens were observed individually for the presence of ectoparasites, as well as deformities, erosions, lesions, etc.

Histological assay. Transversal sections were prepared according to standard procedures (Howard \& Smith 1983). From scallops, samples were taken from gills, hepatopancreas, gonads and kidneys. Tissues were fixed in buffered $4 \%$ formol, embedded in paraffin, sectioned at $5 \mu \mathrm{m}$, stained with hematoxylin/eosin /saffron (HES), and examined in a light microscope (screened at 40 or $100 \times$, details examined at 400 or $1000 \times$ magnification). Hemolymph smears from Ostrea edulis (see Table 1) were stained in Diff-Quik (Baxter Dade AG) and observed in light microscope at $1000 \times$ magnification.

Virological assay. The Chinook Salmon Embryo (CHSE-214) cell line was used in virological assays. Cells were cultured in the Earles modification of the Minimum Essential medium (EMEM) (Flow) supplied with $10 \%$ foetal bovine serum (Flow), 1\% non-essential amino acids (Flow) and $100 \mathrm{mg}$ Gentamicin (Schering) $1^{-1}$ 
Table 1 Sampling of commercially exploited bivalve molluscan species in Norway from autumn 1989 to spring 1992. hs: heart smears

\begin{tabular}{|c|c|c|c|c|c|c|c|}
\hline \multirow[t]{2}{*}{ Species } & \multirow{2}{*}{ Location } & \multirow{2}{*}{$\begin{array}{c}1989 \\
\text { Autumn }\end{array}$} & \multicolumn{2}{|c|}{1990} & \multicolumn{2}{|l|}{1991} & \multirow{2}{*}{$\begin{array}{l}1992 \\
\text { Spring }\end{array}$} \\
\hline & & & Spring & Autumn & Spring & Autumn & \\
\hline \multirow[t]{2}{*}{ Ostrea edulis } & Espevik & $\begin{array}{l}50 \\
50 \text { hs }\end{array}$ & $\begin{array}{l}150 \\
20 \text { hs }\end{array}$ & 30 & 150 & 40 & 50 \\
\hline & Văgstranda & $\begin{array}{l}35 \\
35 \text { hs }\end{array}$ & & 40 & & & $\begin{array}{l}40 \\
50 \mathrm{hs}\end{array}$ \\
\hline Crassostrea gigas & $\begin{array}{l}\text { Espevik } \\
\text { Rognvoll }\end{array}$ & & $\begin{array}{l}40 \\
40\end{array}$ & 30 & & 40 & 40 \\
\hline Ruditapes philippinarum & Espevik & 40 & 40 & 40 & 150 & 40 & 40 \\
\hline R. decussatus & Espevik & & & & $\begin{array}{l}25 \\
\text { Broodstock }\end{array}$ & $\begin{array}{ll} & 40 \\
\mathrm{k} & \text { Spat }\end{array}$ & $\begin{array}{l}40 \\
\text { Juvenile }\end{array}$ \\
\hline Pecten maximus & & $\begin{array}{l}80 \text { gill } \\
50 \text { hepatopancreas } \\
30 \text { gonad } \\
30 \text { kidney }\end{array}$ & & & & & \\
\hline
\end{tabular}

At each sampling, hepatopancreas tissue was dissected from 10 specimens, pooled, diluted $1: 1$ in EMEM and pounded in a Stomacher Lab-Blender 80 (Seward Lab.). Homogenates were diluted 1:49 and filtered through $0.2 \mu \mathrm{m}$ disc filters. Filtrates $(2 \mathrm{ml})$ were inoculated onto CHSE cell culture monolayers in $25 \mathrm{~cm}^{2}$ Nunclon cell culture bottles and incubated at $20^{\circ} \mathrm{C}$ for $7 \mathrm{~d}$. Supernatants were passed onto new cell cultures twice, at $1 \mathrm{wk}$ intervals.

\section{RESULTS}

No mortality of Ostrea edulis was observed by inspection in the poll, and no mass mortalities of broodstock Crassostrea gigas, Ruditapes philippinarum or $R$. decussatus were observed by inspections on the site.

No cytopathic effect was observed on the CHSE-214 cell culture inoculated with homogenates from any sample.

\section{Gross morphology and histological examinations}

European flat oysters Ostrea edulis. The screening did not reveal any sign of serious pathogenic agents, either by observation of gross morphology or by microscopical examination of sections and smears. A general observation was emaciated specimens, frequently with pale digestive glands. Microscopical examinations frequently revealed moderately dilated digestive tubules with relatively low epithelial layers.

The shells of a few specimens revealed boring sponges Cliona sp. No severe infestations were observed, and on some specimens only the small holes in the shells were observed.

Thigmotrich ciliates were observed on gills and/or in the lumina of digestive diverticula of specimens from both Vågstranda and Espevik. Prevalence was maximum $10 \%$, and the intensity was maximum 15 ciliates per section. From observation in the histological sections (Fig. 2a, b), the length was estimated to be 35 to $45 \mu \mathrm{m}$, and the ciliates were assumed to belong to the family Ancistrocomidae. No pathological changes were observed.

Dense, finely granular, basophilic inclusions were observed in the epithelia of digestive gland tubules of specimens from both sites (Fig. 2c). Prevalence was maximum $12 \%$ and the intensity was maximum 5 per section. No inflammation was observed, indicating that the inclusions were intracytoplasmic. The inclusions presumably represent colonies of Rickettsiales-like organisms.

Polymorphic granulation resembling inorganic crystals or precipitates was observed in specimens from Tysnes. The granulations were normally negligible to moderate, but moderate to massive in $93 \%$ of the specimens sampled in spring 1991 (Fig. 2d). Granulations were localized in connective tissue surrounding the stomach and intestine, frequently in the stomach and intestine epithelia, and occasionally in and surrounding the digestive gland tubules. The granulations were often surrounded by massive hemocytic infiltrations (Fig. 2e). In some specimens aggregated or flocculated matter was also observed in the stomach. This material seemed to cause some degradation or erosion of the 

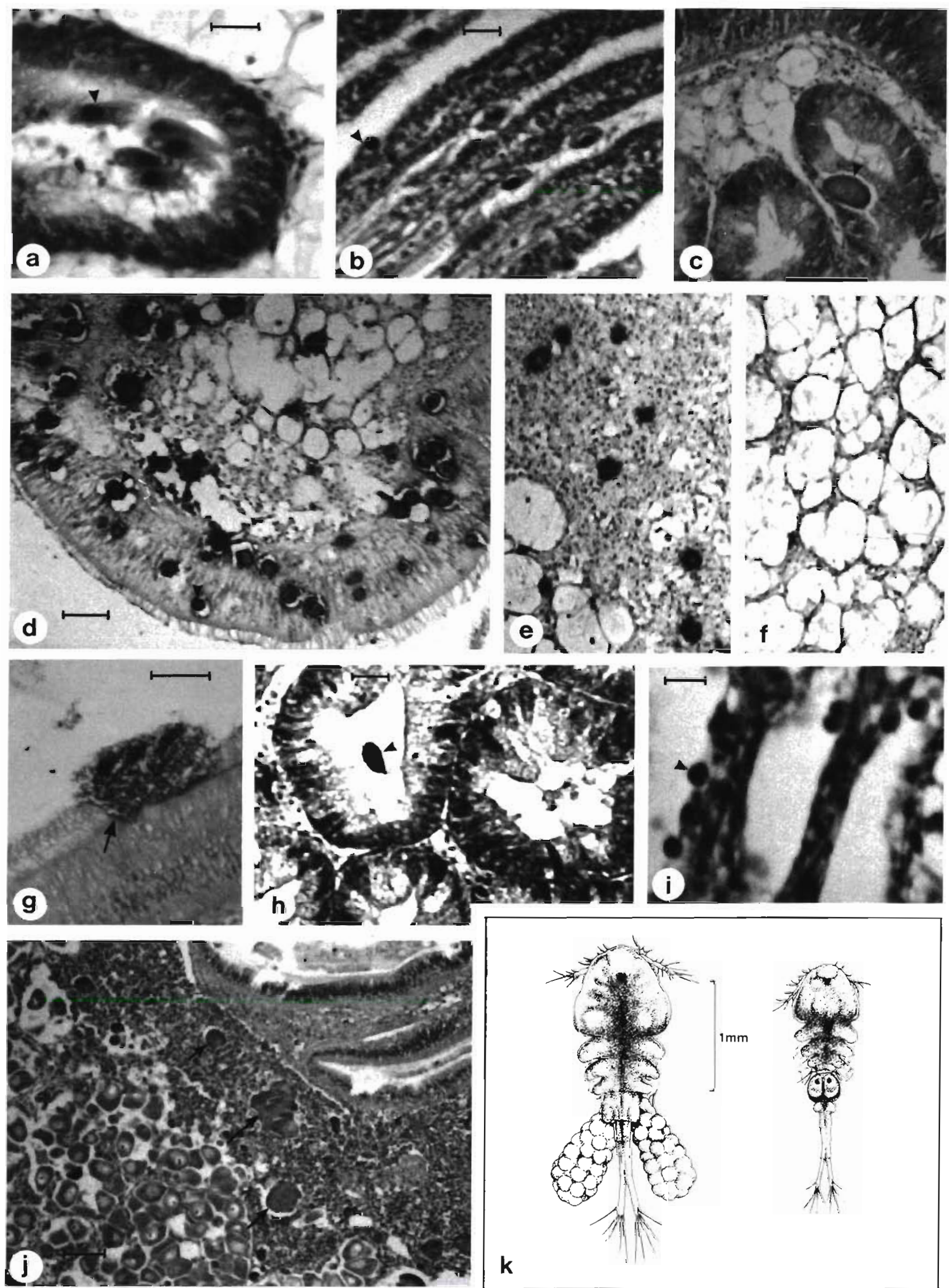
ciliated epithelium of the stomach wall (Fig. $2 g$ ). As the poll was fertilized with silicate during spring and summer until 1991, and the observed material in tissues and stomach lumina were suspected to be precipitated inorganic material, oysters sampled in March 1992 were collected at different locations in the poll, at varying distances from the silicate doser (see Fig. 1c). Granules were observed in a few of these specimens. In most specimens dense hemocytic aggregations were observed in the connective tissue surrounding the stomach

Pacific oysters Crassostrea gigas. No abnormalities, nor any pathogenic agent, were observed in Pacific oysters. Two different ciliates were observed. Ciliates resembling those found in flat oysters were observed in lumina of the digestive diverticula and in the intestine of a maximum of $23 \%$ of the specimens (Fig. 2h). The intensity was maximum 11 per section. In some specimens a smaller (10 to $14 \mu \mathrm{m}$ ) ciliate (Fig. 2i) was observed on the gill surface, where it appeared to be numerous in a few specimens. Moderate crystallizations were observed in the connective tissues and the stomach epithelia of a few specimens collected in 1990 , 1991 and 1992. Frequently the oysters were emaciated, and appeared in a poor physiological state.

Manila clams Ruditapes philippinarum. No pathogenic agent was observed in the Manila clams. In general, the histological examinations revealed highly variable, but probably 'normal' tissue conditions reflecting the physiological status of the clams, and thus different degrees of stress. The thickness and degree of vacuolization of digestive diverticula epithelial layers was variable, and in some specimens sloughed cells were observed in lumina. Focal hemocytic aggregations were occasionally observed in different tissues, in some cases in connection with the presence of eosiniphilous, polymorphic, presumably organic material most likely originating from digested material or gonad resorption (Fig. 2j). Some shell deformities were observed, and in some specimens brownish conchiolin deposits were observed on the inner shell surface, by the edge of the mantle. Mature eggs and sperm were observed in most samplings, both in spring and autumn.

Clams Ruditapes decussatus. No clear pathological changes were observed in either adult or spat. Although not judged as pathological changes, some notable conditions were observed in tissues of the 25 broodstock specimens (collected from a wild popula tion). There were: Gonads were empty. Focal hemocytic aggregations were observed in connective tissues in half of the specimens, and massive crystallization was observed in the kidney of one specimen. The digestive tubule and diverticula epithelia appeared thin and highly vacuolized. Tubule lumina contained sloughed cells and secretions. Gill epithelia were in some cases slightly hyperplastic, and aggregations of hemocytes and a high number of brown cells were present in the gill filaments. Structures resembling encysted nematode larvae were observed in 3 specimens.

Scallops Pecten maximus. By observation of gross morphology, 2 to 6 free-moving cyclopoid copepods (Fig. $2 \mathrm{k}$ ) were observed on the gills of most specimens. The size was from 1.6 (male) to $2.7 \mathrm{~mm}$ (female). From size and morphological features these were presumed to be Modiolicola sp., probably Modiolicola maximus (Reddiah \& Williamson 1959, Humes \& Stock 1973). Similar copepods, probably of the same species, have previously been observed in scallops from different sites on the Norwegian western coast $(\varnothing$. Strand pers. comm.).

Histological examinations did not reveal any pathological changes in the gill, hepatopancreas, gonad or kidney tissues. In 3 specimens 1 or 2 encysted single digenean metacercaria were observed in, or at the basis of, the gills.

\section{DISCUSSION}

During this survey no abnormal mortalities were registered, nor any serious pathogenic agents detected. Although relatively few specimens from a few sampling points were examined, the survey should reveal the most feared and harmful bivalve molluscan parasites if they were present in the stocks.

The most serious threat to the Norwegian stocks is probably the intrahemocytic protozooan (Ascetospora) flat oyster parasite Bonamia ostreae (Comps et al. 1980, Pichot et al. 1980). The introduction of this parasite into new regions is in general followed by massive

Fig. 2. (a to g) Ostrea edulis. (a) Five thigmotrich ciliates in the lumen of a digestive diverticula, and (b) on gills. (Bars $=20 \mu \mathrm{m}$ ). (c) Finely granular basophilic structure in digestive diverticula epithelium resembling a colony of Rickettsiales-like organisms. (d) Polymorphic, presumably crystalline structures in stomach epithelium and underlying connective tissue. (Bar $=50 \mu \mathrm{m})$. (e) Massive infiltration of hemocytes in connective tissue with structures as shown in (d). (f) Normal connective tissue for comparison with (e) (scale as in [d]). (g) Granulous or flocculated material in stomach. Note erosion or degradation of ciliated epithelium (arrow) (bar $=50 \mu \mathrm{m}$ ). (h \& i) Crassostrea gigas. (h) Single thigmotrich ciliate in the lumen of a digestive diverticula, and (i) ciliates on gills. (Bars $=20 \mu \mathrm{m}$ ). (j) Ruditapes philippinarum. Eosinophilous, polymorphic, presumably organic material (arrows) and massive infiltration of hemocytes in connective tissue. (Bar $=100 \mu \mathrm{m}$.) (k) Pecten maximus. Cyclopoid copepods from gill. Female (left) and male, drawn from fresh specimens 
mortalities of flat oysters Ostrea edulis, and other flat oyster species, such as Ostrea puelchana, Tiostrea chilensis and Ostrea angasi, have proven to be susceptible (Grizel et al. 1983, Bougrier et al. 1986, Dinamani et al. 1987, Hine 1991, M. Pascual pers. comm.). There have been no known introductions of flat oysters into Norway since $B$. ostreae was spread to European stocks after its introduction in Brittany, France, in 1979 (Elston et al. 1986). The examinations of flat oysters support the previous assumption that Norwegian flat oysters $O$. edulis are free of Bonamia sp.

The protozoon (Apicomplexa) parasite Perkinsus marinus (see Levine 1978) was mainly known to affect the American oyster Crassostrea virginica (see Mackin et al. 1950), but, as reviewed by Lauckner (1983), $P$. marinus or Perkinsus sp. have been reported from a variety of bivalve molluscan species. Amongst their host species, Perkinsus sp. occur as pathogens also for the clam Ruditapes decussatus (Comps \& Chagot 1987. Azevedo 1989). As reviewed by Lauckner (1983) sporulation seems to be temperature and salinity-dependent. Both temperature and salinity are highly variable in the poll at Espevik, and the temperature frequently exeeds $25^{\circ} \mathrm{C}$ during summer ( $\varnothing$. Strand pers. comm.). Bivalve molluscan species in the poll will thus frequently have experienced environmental conditions which are highly favourable for the parasite. As no mortalities have been recorded, and no Perkinsus has been observed in the histological sections, both the stocks of $R$. philippinarum and the indigenous $R$. decussatus appear free from this parasite.

Rickettsiales-like organisms (RLO) in gill tissues of scallops Pecten maximus have been proposed to be the cause of mass mortalities of this species in France (Le Gall et al. 1988). In their studies, Le Gall et al. (1991) also examined a limited number of scallops from Norway. RLO were not detected in these specimens, and their findings are in accordance with the results from the present study of scallops from Sotra. However, structures resembling rickettsial colonies were observed in the Norwegian flat oyster. As summarized by Fries et al. (1991), RLO have been detected in different tissues of a variety of bivalve molluscan species. The present observations of low prevalence and intensity, and no apparent pathological effect in the oysters, might support the assumption that these procaryotes are widely distributed in the aquatic environment and occur in a variety of marine species.

A variety of protozoans are normally found on tissue surfaces and in the digestive system of bivalve molluscs. Fenchel (1965) reported 47 morphologically different ciliates from bivalve molluscs in Scandinavia, most of which are probably commensals more or less specifically adapted to their host. In the oysters examined in the present study, the prevalence and intensity of ciliates were low, and no pathological changes were observed. The ciliates were therefore considered to be a part of the oysters' normal microbial fauna.

Aggregations of hemocytes in flat oysters from Espevik indicated that the observed crystallization or granulations in the tissues caused an irritation which could represent a stress, and be detrimental to the oysters. It has been shown experimentally by Alvarez et al. (1992) that abiotic particles which were taken up from the alimentary tract by motile oyster hemocytes were relocalized in different tissues, and later gradually removed. Absence of granulations but presence of hemocytic aggregations in the sample of flat oysters from spring 1992 may indicate that the observed material in the present samples had been removed by motile hemocytes. Such removal of both biotic and abiotic materials are known to be conducted by bivalve hemocytes (Stauber 1950, Tripp 1960, Feng 1965). If fertilization of the poll continues, further investigations, as well as experimental work, are necessary in order to elucidate the observed phenomenon.

Several samplings of both oysters and clams revealed emaciated specimens, in many cases probably starved, and in poor physiological condition. In general starved and weakened animals have an increased susceptibility to diseases, and in bivalves, starvation and temperature stress may lead to temporary degeneration of hepatopancreas tubule structures (Thompson et al. 1974). Attention should be paid to stocking density of bivalves in these facilities.

Although they appeared emaciated in some samplings, the Manila clams were, as stated above, apparently devoid of serious parasites. The presented results are probably in accordance with the results from thorough examinations of this species in Canada (Bower et al. 1992). Observations of sexually mature Manila clams are also noteworthy. These bivalves were held in an ambient flow-through mixture of poll and fjord-water, and the observations thus suggest that the Manila clam is capable of reproducing under the local environmental conditions. Also this could be in accordance with the case in Canada, where this species, since being unintentionally introduced in the 1930s (Quayle 1964) has reproduced freely and colonized large areas along the Washington and British Columbia coastline (Holland \& Chew 1974, Bourne 1982). From an ecological viewpoint it should therefore be investigated whether wild Manila clam populations have become established in the Norwegian fauna.

\section{CONCLUSIONS}

To date, no serious infectious diseases or parasites have been detected in stocks of commercially ex- 
ploited bivalve molluscs in Norway. In order to manage our stocks, a continuous, organized survey, satisfying international standards, is strongly recommended.

Due to disease problems in the production of bivalve molluscs in Europe, the availability of disease-free specimens for use as broodstock, and for grow-out in intensive production, indeed represents a valuable resource. The risk of introducing pathogenic agents must thus not be ignored when considering any introduction of live bivalve molluscs into Norway.

Acknowledgements. The author is indebted to a number of colleagues, especially to Ingrid Uglenes and Lisbeth Harkestad for excellent technical assistance, and help with screening the histological sections. Thanks to Øivind Strand, Paul T Solberg, Alf Roald Sætre, Thorolf Magnesen, Bjorn Berland, Egil Karlsbakk and Glenn Bristow for help, advice and useful information, and to Johan Glette and Glenn Bristow for criticism of the manuscript. Special thanks to Henri Grizel at IFREMER, La Tremblade, France, and Susan M. Bower at Dept of Fisheries and Oceans, Nanaimo, Canada for assistance with interpreting histological sections and to Ralph A. Elston at Battelle, Pacific Northwest Laboratories, Washington, USA and Dominique Chagot, at IFREMER, La Tremblade, France for histological reference sections. This work was supported by the Norwegian Fisheries Research Council.

\section{LITERATURE CITED}

Alvarez, M. R., Friedl, F. E., Hudson, C. M., O'Neill, R. L. (1992). Uptake and tissue distribution of abiotic particles from the alimentary tract of the American oyster: a simulation of intracellular parasitism. J. Invert. Pathol. 59: $290-294$

Anonymous (1991). Council Directive of 28 January 1991 (91/67/EEC), concerning the animal health conditions governing the placing on the market of aquaculture animals and products. Official Journal of the European Communities, No. L 46/l

Azevedo, C. (1989). Fine structure of Perkinsus atlanticus n. sp. (Apicomplexa, Perkinsea) parasite of clams, Ruditapes decussatus from Portugal. J. Parasitol. 75: 627-635

Bougrier, S., Tige, G., Bachere, E., Grizel, H. (1986). Ostrea angazi acclimatization to French coasts. Aquaculture 58: $151-154$

Bourne, N. (1982). Distribution, reproduction, and growth of Manila clam, Tapes philippinarum (Adams and Reeves), in British Columbia. J. Shellfish Res. 2(1): 47-54

Bower, S. M., Blackbourn, J., Meyer, G. R. (1992). Parasite and symbiont fauna of japanese littlenecks, Tapes philippinarum (Adams and Reeve, 1850), in British Columbia. J. Shellfish Res. 11(1): 13-19

Comps, M., Chagot, D. (1987). Une parasitose nouvelle chez la palourde Ruditapes decussatus L. C. r. Acad. Sci. Paris 304, série III, no. 1: 41-44

Comps, M., Tige, G., Grizel, H. (1980). Recherches ultrastructurales sur un protiste parasite de l'huitre plate Ostrea edulis L. C. r. Acad. Sci. 290(D): 383-384

De Kinkelin, P., Håstein, T., Krecek, J., Chen, S. N., Hill, B. J., (1990). The role of the OIE (Office International des Epizooties) in improving awareness and control of international transfers of fish and shellfish diseases. Bull. Eur. Ass. Fish Pathol. 10(1): 4-6
Dinamani, P., Hine, P. M., Jones, J. B. (1987). Occurrence and characteristics of the haemocyte parasite Bonamia sp. in the New Zealand dredge oyster Tiastrea Jutarica. Dis. aquat. Org. 3: $37-44$

Elston, R. A., Farley, C. A., Kent, M. L. (1986). Occurrence and significance of bonamiasis in European flat oysters Ostrea edulis in North America. Dis. aquat. Org. 2: 49-54

Fenchel, T (1965). Ciliates from Scandinavian molluscs. Ophelia 2(1): $71-174$

Feng, S. Y (1965). Pinocytosis of proteins by oyster leucocytes. Biol. Bull. 128: 95-105

Fries, C. R., Grau, S. B., Tripp, M. R. (1991). Rickettsiae in the cytoplasm of gill epithelial cells of the soft-shelled clam Mya arenaria. J. Invert. Pathol. 57: 443-445

Gaarder, T., Bjerkan, P. (1934). Osters og østerskultur i Norge. J. Grieg Boktrykkeri, Bergen (in Norwegian)

Grizel, H., Comps, M., Raguenes, D., Leborgne, Y., Tige, G., Martin, A. G. (1983). Bilan des essais d'acclimatation d'Ostrea chilensis sur les côtes de Bretagne. Rev. Trav. Inst. Pêches marit. 46(3): 209-225

Helland-Hansen, B. (1908). Die Austernbassins in Norwegen. Int. Rev. ges. Hydrobiol. Hydrogr. 1: 553-573 (in German)

Hill, B. J. (1982). Infectious pancreatic necrosis virus and its virulence. In: Roberts, R. J. (ed.) Microbial diseases of fish. Academic Press, London, p. 91-114

Hine. P. M. (1991). The annual pattern of Bonamia sp. in New Zealand flat oysters, Tiostrea chilensis. Aquaculture 93: 241-251

Holland, D. A., Chew, K. K. (1974). Reproductive cycle of the Manila clam (Venerupis japonica), from Hood canal, Washington. Proc. natn. Shellfish, Ass. 64: 53-58

Howard, D. W., Smith, C. S. (1983). Histological techniques for marine bivalve mollusks. NOAA Technical Memorandum NMFS-F/NEC-25, Woods Hole, MA

Humes, A. G., Stock, J. H. (1973). A revision of the family Lichomolgidae Kossmann, 1877, cyclopoid copepods mainly associated with marine invertebrates. Smithson. Contr. Zool. 127: 368 p.

Lauckner, G. (1983). Diseases of Mollusca: Bivalvia. In: Kinne, O. (ed.) Diseases of marine animals, Vol. II. Introduction, Bivalvia to Scaphopoda. Biologische Anstalt Helgoland, Hamburg, p. 477-879

Le Gall, G. Chagot, D., Mialhe, E., Grizel, H. (1988). Branchial Rickettsiales-like infection associated with mass mortality of sea scallop Pecten maximus. Dis. aquat. Org. 4: $229-232$

Le Gall, G., Mialhe, E., Chagot, D., Grizel, H. (1991). Epizootiological study of rickettsiosis of the Saint-Jaques scallop Pecten maximus. Dis aquat. Org. 10: 139-145

Levine, N. D. (1978). Perkinsus gen. n. and other new taxa in the protozoan phylum Apicomplexa. J Parasitol. 64(3): 549

Mackin, J. G., Owen, H. M., Collier, A. (1950). Preliminary note on the occurrence of a new protistan parasite, Dermacystidium marinum n. $\mathrm{sp}$., in Crassostrea virginica (Gmelin). Science 111: 328-329

Matthews, J. B. L., Heimdal, B. R. (1980). Pelagic productivity and food chains in fjord systems. In: Freeland, H. J., Farmer, D. M., Levings, C. D. (eds.). Fjord oceanography. Plenum Press, New York p. 337-397

Mortensen, S. H., Bachere, E., Le Gall, G., Mialhe, E. (1992) Persistence of Infectious pancreatic necrosis virus (IPNV) in scallops (Pecten maximus). Dis. aquat. Org. 12: 221-227

Mortensen, S. H., Hjeltnes, B., Rodseth, O., Krogsrud, J., Christie, K. E. (1990). Infectious Pancreatic Necrosis Virus, serotype N1 isolated from Norwegian turbot (Scopthalmus 
maximus), halibut (Hippoglossus hippoglossus) and scallops (Pecten maximus). Bull. Eur. Ass. Fish Pathol. 10(2): $42-43$

Pichot, Y., Comps, M., Tige, Grizel, H., Rabouin, M. A. (1980). Recherches sur Bonamia ostreae gen. n., sp. n., parasite nouveau de l'huitre plate Ostrea edulis L. Rev. Trav. Inst. Pêches Marit. 43: 131-140

Quayle, D. B. (1964). Distribution of introduced marine mollusca in British Columbia waters. J. Fish. Res. Bd Can. 21(5): 1155-1181

Reddiah, K., Williamson, D. I. (1959). On Modiolicola inermis Canu and Modiolicola maxima (Thompson), lichomolgid

Responsible Subject Editor: A. K. Sparks, Seattle, Washington, USA copepods associated with pectinid lamellibranchs. Ann Mag. Nat. Hist. Ser. 13, 1: 689-701

Stauber, L. A. (1950). The fate of india ink injected intracardially into the oyster, Ostrea virginica Gmelin. Biol. Bull. 98: $227-241$

Thompson, R. J., Ratcliffe, N. A., Bayne, B. L. (1974). Effects of starvation on structure and function in the digestive gland of the mussel (Mytilus edulis L.). J. mar. biol. Ass. UK 54: $699-712$

Tripp, M. R. (1960). Mechanisms of removal of injected microorganisms from the American oyster, Crassostrea virginica (Gmelin) Biol. Bull. 119: 210-223

Manuscript first received: December 9, 1992

Revised version accepted: May 12, 1993 